\title{
TAF5 wt Allele
}

National Cancer Institute

\section{Source}

National Cancer Institute. TAF5 wt Allele. NCI Thesaurus. Code C52606.

Human TAF5 wild-type allele is located within 10q24-q25.2 and is approximately $21 \mathrm{~kb}$ in length. This allele, which encodes transcription initiation factor TFIID subunit 5 protein, is involved in the modulation of the formation of a transcriptional complex containing RNA polymerase II and other initiation factors. 